\title{
Stimulation, Detection, and Early Intervention of Growth of Children Aged 1-5 Years Old for Healthcare Center's Cadre and Parents at Kenarilang Health Center, Alor
}

\author{
Odi L. Namangdjabar*, Ummi Kaltsum S. Saleh
}

Lecturer at Health Polytechnic Ministry of Health Kupang, Department of Midwifery

\section{Article History}

Received: 08.12 .2020

Accepted: 24.12 .2020

Published: 30.12 .2020

Journal homepage:

https://www.easpublisher.com

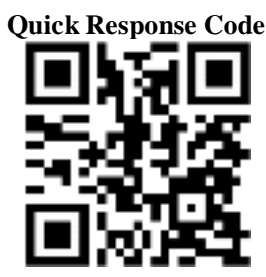

Abstract: Background: The growth and development of children will vary from one child to another. Development focuses on changes that occur gradually from the lowest level to the highest and most complex levels through the process of maturation and learning. Development relates to changes in quality, including an increase in individual capacity to function which is achieved through a process of growth, maturation, and learning. Subjects and Method: This study aims to determine knowledge, change attitudes and behavior of parents regarding Stimulation, Detection, and Early Intervention for children aged 1-5 years at Kenarilang Health Center, Alor.Descriptive research data collection based on cross sectional approach. The population taken in this study was all healthcare center's cadres and mothers who have children aged 1-5 years who live in the working area of Kenarilang Health Center, Alor, totaling 252 people. The technique for determining the sample is proportional random stratification. The number of samples used in this study was 50 samples. Results: Most of the respondent's as many as 27 people $(54.0 \%)$ had a lack of ability to stimulate growth and development, as many as 42 people $(84.0 \%)$ had a good ability to detect growth and development, and 46 people $(92.0 \%)$ had good abilityat interventions for growth and development. Conclusion: Most of the respondents have less ability to stimulate growth and development. Most of the respondents have less ability to detect growth and development. Most of the respondents have a good ability in conducting growth and development interventions.

Keywords: Stimulation, early detection and intervention.

Copyright (C) 2020 The Author(s): This is an open-access article distributed under the terms of the Creative Commons Attribution 4.0 International License (CC BY-NC 4.0) which permits unrestricted use, distribution, and reproduction in any medium for non-commercial use provided the original author and source are credited.

\section{INTRODUCTION}

Research on the children fewer than five in various regions in Indonesia shows that there are still many parents who only master a little how to raise children. This is confirmed by Sacharin that families must be able to care for their children according to the level of development and growth, which with good parenting allows children to grow and develop according to their developmental stages so that children do not experience mistreatment from parents. This research reflects that there are many problems in child development in developing countries. This can be seen from the fact that there are still many parents who still ignore what their children need in achieving optimal development. Many parents think that children's development does not require special attention. This condition was strengthened from the initial survey of 10 mothers in Pucuk Village where data was obtained that $6(60 \%)$ mothers had not implemented proper parenting methods, while (40\%) mothers had implemented proper childcare practices. They assume that if their child's physical growth is normal then their development will not be a problem and that the child's development does not require special attention so that this can interfere with the child's development.

Various factors that can lead to improper childcare include: knowledge, culture, environment, and family. Adequate family knowledge about child development will be used by the family as the basis for carrying out correct care, including by stimulating and early detection of developmental irregularities. This is in accordance with the concept that behavior based on knowledge, awareness, and positive attitudes will last, on the other hand, with lack of knowledge, the care that is carried out is also inadequate [1].

The family has a big influence on the development of their children, if the family does not support their child's development efforts or does not seek to obtain information about the child's development and considers the development of the baby or child to be natural, then the family cannot know whether the child's development is stunted or not, and vice versa. Children who do not get proper care can cause various problems including disruption or delay in 
growth and development. Therefore, early detection of problems and delays in child development is very helpful to prevent the risk of deviation in child development stages, so it takes an active role of parents, one of which is by creating an environment that can stimulate all aspects of child development and mother's knowledge about the development of babies aged 1- 5 years.

To overcome this problem, the government has implemented the Early Detection and Intervention of Growth and Development (SDIDTK) program and the Maternal Child Health Book as a means of communication, education, and health monitoring as well as the role of the private sector regarding the installation of posters, leaflets, and so on, but in fact there is still a problem of poor parenting. Therefore, nurses need to increase their role, especially by providing proper counseling about childcare so that parents' knowledge of child development tasks can increase because the family is the smallest part of society, and it is in that family that the quality of children's growth and development is determined. The family can also meet the children's needs for nurture, love, and care.

\section{Research Type and Design}

The study used a descriptive research method and data collection was based on a cross sectional approach [2, 3]. The research sample was 50 people.

\section{RESEARCH RESUlT}

\section{Stimulation}

Activities to stimulate the basic abilities of children aged 0-5 years so that children can grow and develop optimally

Table-1: Early Stimulation of Growth and Development of Children aged 0 - 5 Years

\begin{tabular}{|c|l|c|c|}
\hline No & Stimulation & F & \% \\
\hline 1 & Good & 23 & 46.0 \\
\hline 2 & Less & 27 & 54.0 \\
\hline Total & 50 & 100 \\
\hline
\end{tabular}

The table above showed that most of the respondents, as many as 27 people $(54.0 \%)$, had less ability to stimulate growth and development and as many as 23 people (46.0\%) had good abilities in stimulating growth and development.

\section{Detection}

Activities / examinations to find early growth and development deviations in children 1-5 years

Table-2: Early Detection of Growth and Development of Children Aged 0-5 Years

\begin{tabular}{|c|c|c|c|c|}
\hline No & \multicolumn{2}{|c|}{ Detection } & F & \% \\
\hline 1 & Good & 19 & 38.0 \\
\hline 2 & Less & 31 & 62.0 \\
\hline \multicolumn{2}{|c|}{ Total } & 50 & 100 \\
\hline
\end{tabular}

Table 2 showed that most of the respondents, as many as 31 people $(62.0 \%)$, had less ability to detect growth and development and as many as 19 people $(38.0 \%)$ had good ability to detect growth and development.

\section{Intervention}

Activities/examinations to detect early emotional behavior problems, autism, and attention deficit/hyperactivity disorderin children

Table-3: Early Intervention for Growth and Development of Children Aged 0-5 Years

\begin{tabular}{|c|c|c|c|}
\hline No & Intervention & $\mathbf{F}$ & $\%$ \\
\hline 1 & Good & 46 & 92.0 \\
\hline 2 & Less & 4 & 8.0 \\
\hline \multicolumn{2}{|c|}{ Total } & 50 & 100 \\
\hline
\end{tabular}

The table above showed that most of the respondents, as many as 46 people $(92.0 \%)$, had good abilities in interventions for growth and development and as many as 4 people $(8.0 \%)$ had less abilities in interventions for growth and development.

\section{DISCUSSION}

Based on the results of the study, it was shown that most of the respondents, namely 27 people (54.0\%), had less ability to stimulate growth and development, as many as 42 people $(84.0 \%)$ had good abilities in detecting growth and development, and as many as 46 people (92.0\%)have a good ability to intervene in growth and development. The ability of healthcare center's cadres and parents to do stimulation is influenced by knowledge [4]. The knowledge of parents and healthcare center's cadres in stimulating and detecting growth and development is still lacking. This happens because the function of organizing and mobilizing has not been carried out optimally, there are still inhibiting factors for the implementation of the SDIDTK program in Health Center such as there are still people in charge of the SDIDTK program who have never received SDIDTK training, there has been no socialization of the SDIDTK program at the Health Center and its network properly and correctly, supporting facilities for the implementation of the SDIDTK program at the Health Center are still inadequate, and there is a lack of support from the Head of the Health Center for the implementation of this program at the Health Center so that the program's final objectives have not been achieved as expected. However, there are some healthcare center's cadres and parents, as many as 46 percent, have good abilities in stimulating, detecting, and early intervening in growth and development where parents have stimulated according to the stimulation guidelines in the $\mathrm{MCH}$ book and made detection by giving a checklist if the child has an age-appropriate development and gives a cross if the child's development is not age-appropriate. For early development intervention, if the child's development is obtained according to age, the parents 
will continue to stimulate at any time in a pleasant atmosphere and bring children aged 3 months - 2 years every 3 months and ages 2-6 years every 6 months to the facility to get SDIDTK services and if the child's development is not age-appropriate, the parents healthcare center's cadres report it to the midwife at the local healthcare center for further examination. The results of the study also showed that 38 percent of parents did not know and did early detection of development where healthcare center's cadres and parents did not provide a checklist on the box in the $\mathrm{MCH}$ book because they received socialization about the use of the $\mathrm{MCH}$ book in terms of stimulation, detection, and early development intervention which is currently still limited to measuring the child's weight and height. The results of this study are supported by research conducted that the implementation of the SDIDTK program at Health Center and its network is still limited to early detection of growth deviations, while early detection of developmental deviations, emotional mental deviations, and stimulation according to the child's age has not been implemented[5].

Parents and healthcare center's cadreswho have less knowledge have less motivation to stimulate growth and development in the children under five than cadres who have good knowledge about it. The role of healthcare center's cadresas implementers in Healthcare Center activities plays the role of implementing healthcare center activities and mobilizing maternal activeness [6]. For this reason, healthcare center's cadresmust be able to stimulate the growth and development of the children under five at Healthcare Center. Health cadres need to be equipped with knowledge about the role of cadres and knowledge about growth and development so that they can carry out SDIDTK at Healthcare Center [7].

The results of this study indicate that healthcare center's cadresand parents are still lacking in carrying out SDIDTK, therefore it is necessary to increase the ability of healthcare center's cadresand parents in carrying out SDIDTK, so that health workers in the Health Center working area or the Head of Health Center must make training or refresher plans for cadres and parents to increase the knowledge of cadres and parents in SDIDTK. Cadres can be provided with SDIDTK knowledge through refreshing the use and utilization of the $\mathrm{MCH}$ book, which contains early detection and simple stimulation of growth and development that can be done by cadres of parents / families.

A person who has good knowledge about growth and development will generate motivation and the importance of stimulating and early detection of growth and development in the children under five so that the next generation does not experience growth and development delays that have an impact on dependence if intervention is not carried out as early as possible.
Midwives as health workers at the Health Center or as midwives in their working areas have a role in increasing the knowledge of cadres and parents in stimulating, detecting, and early intervening growth and development of children under five, especially in Healthcare Center. Midwives have roles and responsibilities in stimulating and early detection of children under five's growth and development in accordance with Regulation of the Health Ministry 1464 of 2012, so midwives must work together with cadres to be able to carry out their roles in Healthcare Center or the community. The results of this study were supported that knowledge was significantly related to cadres' motivation in detecting the children under-five's growth and development. The knowledge of healthcare center's cadres and parents is needed in increasing the motivation of healthcare center's cadres and parents in carrying out SDIDTK [8].

\section{Conclusion}

Based on the results of this processing, it can be concluded that, most of the respondents have a lack of ability to stimulate growth and development, most of the respondents have less ability to detect growth and development and most of the respondents have a good ability to intervene in growth and development.

\section{REFERENCES}

1. Notoatmodjo, S. (2007). Promosi kesehatan dan ilmu perilaku. Jakarta: rineka cipta, 20.

2. Sulistyaningsih, H. (2011). Metodologi Penelitian Kebidanan Kuantitatif Kualitatif. Jakarta: Graha Ilmu.

3. Riyanto, G. I. (2011). Aplikasi Metodologi Penelitian Kesehatan.

4. Soetjiningsiht, E.G.C. (2014). Tumbuh Kembang Anak.

5. Maritalia, D. (2009). Analisis pelaksanaan program stimulasi, deteksi dan intervensi dini tumbuh kembang (SDIDTK) balita dan anak pra sekolah di Puskesmas Kota Semarang tahun 2009 (Doctoral dissertation, Program Pasca Sarjana Universitas Diponegoro).

6. Depkes, R. I. (2006). Pedoman pelaksanaan stimulasi, deteksi dan intervensi dini tumbuh kembang anak di tingkat pelayanan kesehatan dasar. Jakarta: Depkes RI, 7-49.

7. Syofiah, P. N., Machmud, R., \& Yantri, E. (2020). Analisis Pelaksanaan Program Stimulasi, Deteksi dan Intervensi Dini Tumbuh Kembang (SDIDTK) Balita di Puskesmas Kota Padang Tahun 2018. J. Kesehat. Andalas8, 151-156.

8. Aticeh, A., Maryanah, M., \& Sukamti, S. (2015). Pengetahuan Kader Meningkatkan Motivasi Dalam Melakukan Deteksi Dini Tumbuh Kembang Balita. Jurnal ilmu dan teknologi kesehatan, 2(2), 71-76. 